\title{
An Introduction to Tourism Postdisciplinarity
}

\author{
Munar, Ana Maria; Pernecky, Tomas ; Feighery, William
}

Document Version

Final published version

Published in:

Tourism Analysis

DOI:

$10.3727 / 108354216 \times 14600320851578$

Publication date:

2016

License

Unspecified

Citation for published version (APA):

Munar, A. M., Pernecky, T., \& Feighery, W. (2016). An Introduction to Tourism Postdisciplinarity. Tourism Analysis, 21(4), 343-347. https://doi.org/10.3727/108354216X14600320851578

Link to publication in CBS Research Portal

\section{General rights}

Copyright and moral rights for the publications made accessible in the public portal are retained by the authors and/or other copyright owners and it is a condition of accessing publications that users recognise and abide by the legal requirements associated with these rights.

Take down policy

If you believe that this document breaches copyright please contact us (research.lib@cbs.dk) providing details, and we will remove access to the work immediately and investigate your claim. 


\section{An Introduction to Tourism Postdisciplinarity}

\section{Ana Maria Munar, Tomas Pernecky, and William Feighery}

Journal article (Final published version)

CITE: An Introduction to Tourism Postdisciplinarity. / Munar, Ana Maria; Pernecky, Tomas ; Feighery, William. In: Tourism Ana/ysis, Vol. 21, No. 4, 2016, p. 343-347.

DOI: $10.3727 / 108354216 \times 14600320851578$

Uploaded to Research@CBS: January २०18 


\title{
AN INTRODUCTION TO TOURISM POSTDISCIPLINARITY
}

\author{
ANA MARÍA MUNAR,* TOMAS PERNECKY,† AND WILLIAM FEIGHERY \\ *Department of International Economics and Management, Copenhagen Business School, \\ Copenhagen, Denmark \\ †School of Hospitality and Tourism, Auckland University of Technology, Auckland, New Zealand \\ ¥The Research Methods Laboratory, Neuchatel, Switzerland
}

This special issue of Tourism Analysis was born out of the presentations and discussions that took place at the conference "Welcoming Encounters: Tourism Research in a Postdisciplinary Era" (June 19-22, 2013), organized by William G. Feighery and hosted at the Institute of Ethnology, University of Neuchatel, Switzerland. This was the first international conference in Tourism Studies focusing on the topic of postdisciplinarity. In the conference call, the organizers argued that, in common with other fields of enquiry, tourism scholars had begun to explore the productive potential of postdisciplinarity. The notion of postdisciplinarity has been articulated in the seminal works of Coles, Hall, and Duval (2005, 2006, 2009) and by Hollinshead (2010, 2012). Yet, despite their contributions, "there [was] still considerable debate among (some) scholars of tourism as to what a postdisciplinarity approach might entail, or what the outcomes of such a perspective might be" (Feighery, 2013, p. 1). The event in Neuchatel provided an open and inspiring environment to reflect on such questions. The contributors to this special issue share their conceptual and methodological insights about the nature of tourism knowledge production, and they explore the possibilities and challenges that are intertwined with postdisciplinary approaches. The ontological and epistemological nature of tourism research has received much attention throughout the years. Using different perspectives, scholars have attempted to make sense of the ways in which tourism knowledge became possible. Among the key contributions that have focused on the evolution or archaeologies of tourism research are the theory of the platforms by Jafari $(1990,2001)$ and Tribe's (1997) model of modes of knowledge production (Mode 1 and Mode 2). These and other similar works (e.g., Darbellay \& Stock, 2012; Graburn \& Jafari, 1991; Holden, 2005; Jafari \& Ritchie, 1981) concur on several explanatory aspects. First, they take their point of departure in the notion of "original" academic knowledge as something that resides in a series of independent disciplines. Tourism, as a younger academic field, is shown to have evolved from older disciplines and is situated broadly within social sciences. Second, the evolution of tourism research is explained as the process by which novel and larger groups of academics - originally trained in different disciplines - started to examine and contribute to the study of tourism. Third, it is largely agreed that tourism research does not qualify in itself as an academic discipline but is better understood as 
a field of knowledge or a community of academics within a broad spectrum of institutions (e.g., journals, higher education programs). Finally, the combination of scholarly contributions from different disciplines results in the common statement that tourism is a multi- or interdisciplinary field (Tribe, Dann, \& Jamal, 2015).

As indicated by Coles, Hall, and Duval's article in this issue, tourism scholars have a propensity to conflate the terms "multidisciplinary" and "interdisciplinary" (Coles et al., 2006), although there are subtle but important differences among the two. Multidisciplinarity can be described as "a sequential process, in which the researchers from different disciplines work from their perspective on a more or less shared research topic, and in a linear and independent way that does not involve any real interaction between them" (from Darbellay's contribution in this issue). Coles et al. (2009) further clarified that "a multi-disciplinary approach recognizes and incorporates information derived in other disciplinary areas without scholars stepping beyond their own boundaries” (p. 83), whereas interdisciplinarity entails a shared research topic and a higher level of interactivity and coordination among the different researchers. However, as Coles et al. suggested, interdisciplinary enquiry is not to be understood as "permanently abandoning one's disciplinary home so much as temporary or tactical transgression into a different terrain for the purpose of discovery and insight."

The multi- and interdisciplinary thesis has been supported by a series of books and journals that have mapped the academic careers of those that contributed to the birth and evolution of tourism (e.g., the Tourism Social Science series, published by Emerald and edited by Jafar Jafari, and the journal Anatolia's portraits). The first generations of tourism scholars had both a sense of disciplinary theoretical basis and disciplinary identity. At the turn of the millennium, a new wave of intellectuals trained in tourism arrived, adding further to the institutionalization and greater autonomy of the field. This is reflected in the growth of academic journals, textbooks, special interest groups, conferences, and programs. There are, of course, also researchers with a background in a wide range of nontraditional disciplines, such as cultural studies, media studies, environmental sciences, IT design, and so forth. These can be thought of as the embodiment of multi- and interdisciplinarity. Importantly, when considering where knowledge is disseminated, a large proportion of tourism-related research seems to have been published outside of tourism journals (see Coles, Hall, \& Duval's contribution in this issue). These trends suggest an increase in the complexity and diversity of the scholarly groups, career trajectories, and academic identities, and they bring into question the validity of the multi- and interdisciplinarity proposal as the overall epistemic explanation for the creation of knowledge in this field.

\section{The Problem With Disciplinarity}

The establishment of paradigmatic communities of practice within institutional settings, which gave rise to formation of academic disciplines, is relatively recent, emerging in the period from 1750 to 1850 (Carter, 2007). Each scientific discipline came to be regarded as "a distinctive field of experience, inquiry and practice sustained by regulatory systems which identify and authorize the statements which comprise its domain of expertise and legitimized its practitioners" (Holmes, 2001, p. 232). This caused a gradual territorialization of knowledge production through conceptual and methodological imperialism - an evolutionary cul-de-sac within which there is little opportunity to connect with other ways of knowing. Faculties and research institutes were/are the places where knowledge was created, stored, and often shared with specific audiences and those who had authorized access. Scientists often practiced disciplinary closure, resulting in disconnected and disengaged research that was frequently impenetrable to all but in-field specialists. Within these disciplined spaces, social scientists were/are locked into restrictive "lines of enquiry" that result in "mutual incomprehension" and a feeling that "they scarcely have anything to say to one another" (Habermas, 1987, p. 375).

Postdisciplinarity brings into question both the belief that all scientific knowledge creation always originates in disciplinary compartments and the belief that tourism epistemology has to progress only as an inter- or multidisciplinary endeavor. It also challenges the notion that disciplines are 
independent containers of knowledge. Overall, the complex and evolving epistemic landscape depicted above indicates the blurring of boundaries and promising creative potential and reminds us of the discursive nature of knowledge production (Belhassen \& Caton, 2009). This has also been termed "a network of fractional coherence, in which standards, compromises and intellectual innovations are locally negotiated and in which highly diverse knowledges and ways of knowing are assembled and enacted" (Ren, Pritchard, \& Morgan, 2010, p. 890). Emerging reflexive perspectives conceive knowledge as something formed in everyday activities. It is not "built up" from data acquired at static positions, or from selected vantage points, but grows and changes with individuals and the world through which they move (Prezios, 2012, p. 195). The difficulty of maintaining the myth of self-sufficient disciplinary tribes is revealed in one of the volumes that the Tourism Social Science Series has devoted to reconstructing the early history of tourism research through the biographies of pioneer scholars. In the volume titled The Study of Tourism: Anthropological and Sociological Beginnings, Dennison Nash (2005) indicated in the prologue that anthropological and sociological scholars, for example, have "a good deal in common and ties to the other social sciences” (p. 1), and he continued to say that

One often encounters other notions of anthropology and sociology that have different affinities. Indeed, one wonders why the version of sociocultural anthropology offered in an encyclopedia article by Zabel cannot also be applied to sociology. . . . Fields of study have sometimes been distinguished in terms of their subject matter, but as we see in Zabel's attempt at definition, this turns out to be a difficult task where anthropology and sociology (as well as the other social sciences) are concerned. (p. 5)

Nash (2005) questioned not only the divide in the social sciences but also the traditional gulf between humanities and social sciences. It would be difficult to imagine the science of economics without Karl Marx. It would also be difficult to imagine Marx's work if he was not influenced by Immanuel Kant. There would not be an existentialist philosophy without its reflections about psychoanalysis, and there would not be the sociology of gender or religion without the influence of Sigmund Freud. It is equally impossible to imagine the evolution of the last decades of social sciences and humanities without critical and postmodern philosophy. In The Tourist, MacCannell (1999, pp. 39-59) built his popular theory of staged authenticity on the work of Lévi-Strauss and Goffman. Lévi-Strauss, a central figure of anthropology, was highly influenced by the methods of linguistics, and his own work (e.g., on myths) had a major impact on the humanities. "The Tourist Gaze” from Urry, a geographer, is inspired from Foucault (philosopher, social theorist, and philologist) and his theory of the medical gaze. This should not be surprising. Often what characterizes major thinkers throughout history (e.g., Weber, Marx, Freud, Smith, Habermas, and Bourdieu, among others) is that the influence of their work cannot be claimed by only a few specific disciplinary structures and not others. Similar examples of the fluidity of knowledge can be seen between natural sciences and social sciences. Two famous examples come to mind: The first is Darwin's evolutionary theory, which has resulted in evolutionary theorizing about economic, sociological, political, and cultural phenomena. Another is the adaptation of principles of cognitive biology in Luhman's influential theory of social systems. In the case of Darwin's impact on social sciences, we can see that ideas accessed and adapted from distant spheres of knowledge production can transform the essential elements of thinking in fields that are incommensurable. The result is a change in what can be comprehended and how it can be comprehended. It speaks of a disruptive ontological and epistemic innovation that eventually expands and transforms the knowledge of a field or a discipline, with this transformation being incremental or radical in nature.

\section{Envisioning Postdisciplinarity}

Postdisciplinarity addresses the ways in which tourism knowledge is possible. It operates on ontological, epistemological, and methodological levels as discussed in more detail by the contributors to this special issue. However, it is also concerned with the need for knowledge creation that is more 
apt for societies faced with major challenges, such as climate change, economic and financial calamities, global health risks, and geopolitical crises. Solutions to these complex problems cannot be addressed solely from disciplinary islands. As Brewer (2013) has recently observed in the context of the UK,

It is deeply paradoxical, that at a time when the big issues facing the future of mankind are multifaceted and require post-disciplinarily, the social science disciplines remain separated into their own silos. Even more so that disciplinary closure is encouraged by some aspects of higher education policy itself. (p. 48)

Tourism is interconnected with a myriad of worldwide issues - be it SARS, terrorism, destinations' economic development, and environmental concerns, to name a few. As our previous examples show, some of the major thinkers of modernity were experts in getting inspiration from other streams of knowledge. Creativity has always been fostered by the means of nurturing of weak ties and adopting ideas, methodologies, and tools from other domains into one's own (Bilton, 2007). We are in a moment where the ways scholars make sense of the world are colliding with the institutionalized systems of knowledge-that is, the ways educational and scientific institutions frame and reproduce what is to be considered authoritative and valid knowledge. Postdisciplinarity, therefore, is also a critical response to these institutional demands.

This volume begins with Hollinshead's article (which is based on his keynote speech at the 2013 Welcoming Encounters conference), "Postdisciplinarity and the Rise of Intellectual Openness: The Necessity for 'Plural Knowability' in Tourism Studies.” In this text, we meet the academic "tourism judges" and their cultural acts of selection and production. Hollinshead calls for "organic intellectuals" and exposes the dangers of a "darklight tourism" poorly connected to the world and the "fantasmatics" of local/contesting populations. Darbellay's article, "From Disciplinarity to Postdisciplinarity: Tourism Studies Dedisciplined” helps us to put clarity in the "Tower of Babel" of terminology. He presents the tension of historical disciplinary evolution as being a choice between "the abyss and the metamorphosis," and he examines the "ruination of disciplinary worlds." Darbellay envisions a world of researchers with hybrid identities that increasingly release "disciplinary anchors." Coles, Hall, and Duval's article, "Tourism and Postdisciplinarity: Back to the Future?” revisits their seminal work on postdisciplinarity, published in 2006, and provides a highly reflective account of the evolution of the last decade. They envision the expansion of postdisciplinary approaches as a response to research problems that are ever more complex in nature and wide in scope and that can hardly be addressed by disciplines alone.

In the article "Existential Postdisciplinarity: Personal Journeys Into Tourism, Art, and Freedom," Pernecky, Munar, and Wheeller bring us three highly personal creative responses to this debate. We meet the scholar as the "artist" who can mix and blend styles in order to communicate better, and we learn that postdisciplinarity is far from being an "anything goes" attitude, but is instead a careful, meditated form of research. We meet researchers as "disciplinary tourists" with "stolen jackets” searching for academic integrity and are finally called upon to celebrate "the personal" - the creative power that lies in confusion, schisms, and dual identities.

Barry's article, "Packing as Practice: Creative Knowledges Through Material Interactions," advances the term "creative knowledges" in her attempt to emphasize the power of postdisciplinarity to embrace the performative, embodied, and collaborative methods of knowledge generated in the interactions between humans and nonhumans. Barry and Bødker's studies are showcases of a material approach that not only merges a variety of techniques across disciplines but also congeals diverse practical and theoretical influences, utilizing them as required for a specific line of enquiry. Bødker advocates for a polyphony of thinking and the researcher-as-sensor in his article "Getting Lost in the Field." He uses "meditations" as a methodological orientation that allows for an embodied conversation between researcher and place rather than establishing a research enquiry based on predefined protocols derived from dominant disciplinary forces. 
The works included in this special issue present an intellectual debate about the "being" and "becomings" of tourism scientific knowledge. Our hope is that they provide an overview of the complexity of conceptualizing and demarcating postdisciplinary research and stimulate further discussion about how we can know tourism.

\section{References}

Belhassen, Y., \& Caton, K. (2009). Advancing understandings. Annals of Tourism Research, 36(2), 335-352.

Bilton, C. (2007). Management and creativity: From creative industries to creative management. Oxford, UK: Wiley-Blackwell.

Brewer, J. D. (2013). The public value of the social sciences. London, UK: Bloomsbury.

Carter, M. (2007). Ways of knowing, doing, and writing in the disciplines. College Composition and Communication, 58, 385-418.

Coles, T. E., Hall, C. M., \& Duval, D. T. (2005). Mobilising tourism: A post-disciplinary critique. Tourism Recreation Research, 30(2), 53-63.

Coles, T. E., Hall, C. M., \& Duval, D. T. (2006). Tourism and post-disciplinary enquiry. Current Issues in Tourism, 9, 293-319.

Coles, T. E., Hall, C. M., \& Duval, D. T. (2009). Post-disciplinary tourism. In J. Tribe (Ed.), Philosophical issues in tourism (pp. 80-100). Clevedon, UK: Channel View.

Darbellay, F., \& Stock, M. (2012). Tourism as a complex interdisciplinary research object. Annals of Tourism Research, 39(1), 441-458.

Feighery, W. (2013). Welcoming encounters: Tourism research in a postdisciplinary era. Retrieved from https:// www.academia.edu/4215075/Welcoming_Encounters_ Tourism_Research_in_a_Postdisciplinary_Era

Graburn, N. H. H., \& Jafari, J. (1991). Introduction: Tourism and the social sciences. Annals of Tourism Research, $18,1-11$.
Habermas, J. (1987). Theory of communicative action: Vol. 2. Lifeworld and system: A critique of functionalist reason. Boston, MA: Beacon Press.

Holden, A. (2005). Tourism Studies and the social sciences. London, UK: Routledge.

Hollinshead, K. (2010). Tourism Studies and confined understanding: The call for a "new sense" postdisciplinary imaginary. Tourism Analysis, 15, 499-512.

Hollinshead, K. (2012). The under-conceptualisation of Tourism Studies: The case for postdisciplinary knowing. In I. Ateljevic, N. Morgan, \& A. Pritchard (Eds.), The critical turn in Tourism Studies: Creating an academy of hope (pp. 55-72). London, UK: Routledge.

Holmes, C. A. (2001). Postdisciplinarity in mental healthcare: An Australian viewpoint. Nursing Inquiry, 8(4), 230-239.

Jafari, J. (1990). Research and scholarship: The basis of tourism education. Journal of Tourism Studies, 1(1), 33-41.

Jafari, J. (2001). The scientification of tourism. In V. L. Smith \& M. Brent (Eds.), Hosts and guests revisited: Tourism issues of the 21st century (pp. 28-41). New York, NY: Cognizant Communication.

Jafari, J., \& Ritchie, J. R. B. (1981). Toward a framework for tourism education. Annals of Tourism Research, 8(1), 13-34.

MacCannell, D. (1999). The tourist: A new theory of the leisure class. Berkeley, CA: University of California Press.

Nash, D. (Ed.). (2005). The study of tourism: Antropological and sociological beginnings. Bingley, UK: Emerald.

Prezios, D. (2012). Beyond museology: Reframing the sensorium. In I. Haywood \& B. Sandwell (Eds.), The handbook of visual culture (pp. 184-199). London, UK: Berg.

Ren, C., Pritchard, A., \& Morgan, N. (2010). Constructing tourism research. Annals of Tourism Research, 37(4), 885-904.

Tribe, J. (1997). The indiscipline of tourism. Annals of Tourism Research, 24(3), 638-657.

Tribe, J., Dann, G., \& Jamal, T. (2015). Paradigms in tourism research: A trialogue. Tourism Recreation Research, 40(1), 28-47. 